\title{
The Influence of Differences in Income Tax Rules on Income Tax Growth in the Private Tax Taxes and Acceptance of Tax Income in the Office of Jember Pratama Tax Service
}

\author{
Mrenda Ayu Setyowati ${ }^{1}$, Muhaimin Dimyati ${ }^{2}$, Wiwik Fitria Ningsih ${ }^{3}$ \\ Student of STIE Mandala ${ }^{1}$, Lecturer of STIE Mandala ${ }^{2,3}$ \\ Email:dimyati@stie-mandala.ac.id,wiwik@ stie-mandala.ac.id
}

\begin{abstract}
The purpose of this study was to determine the different effects of changes in Non-Taxable Income (PTKP) regulations on the growth rate of the number of Individual Taxpayers (WPOP) and income tax article $21(\mathrm{PPh} 21)$ in the Jember KPP. The data used in this study are secondary data collected from KPP Pratama Jember period 2008-2018. Data processing methods using Descriptive Statistics, Analysis Of Variance (ANOVA) and Multivariate Analysis Of Variance (MANOVA) with SPSS analysis tool version 20. The results of the study show that there are different effects of changes in Non-Taxable Income (PTKP) significantly impacting the growth rate Personal Taxpayers (WPOP) because the rate of growth is increasing and the level of income tax article 21 ( $\mathrm{PPh} 21)$ because the amount of revenue is increasing.
\end{abstract}

Keywords: PTKP, WPOP, Income Tax 21.

\section{INTRODUCTION}

The Directorate General of Tax (DGT) carries out its mission to collect tax revenue, which is directly under the Minister of Finance to determine several types of taxes, one of which is Income Tax $(\mathrm{PPh})$. In the realization of state revenue from the taxation sector from 2008 to 2019, it was stated that the realization of tax revenue was the biggest giving income to the State. Especially in the type of domestic tax that is income tax (PPh) which has a contribution of almost $50 \%$ of the total domestic tax $[3,21]$.

The Directorate General of Taxes in the process of collecting taxes, applies several rules in determining the tax that must be paid by taxpayers, some of which are office expenses, nontaxable income (PTKP) and layered tax rates imposed on taxable income of individual 
taxpayers. These facilities are given to individual taxpayers (WPOP) in order to create justice for every taxpayer from high-income rich taxpayers to lower-income taxpayers. In addition, these facilities are provided so that people are not too burdened with the tax burden that must be paid [7]. One of the facilities provided by the DGT is PTKP, PTKP is used to calculate the amount of taxable income from domestic individual taxpayers who work as employees / employees / laborers / have free work, who has income [2].

Non-taxable income (PTKP), which has been set since tax reform, has no fixed value, from 1983 until the end of 2016, the income limit continues to change. Indonesia has made PTKP adjustments eight times and 5 of them have occurred in the last ten years, namely in 2008, 2009, 2012, 2015 and 2016. If there is an increase in Non-Taxable Income (PTKP) then this will be enjoyed by people who work as employees / employees, and WPOP workers who have free and / or self-employed jobs. PTKP adjusted by the Directorate General of Taxes (DJP) is above the City Minimum Wage [10, 22].

The city minimum wage, which on average still ranges between 1.7 - 3.8 million per month (East Java Governor Decree Number 188/665 / KPTS / 013/2018 About Regency / City Minimum Wages in East Java in 2019) resulted in people who work as an employee / laborer and laborer in East Java reporting tax returns with a tax to be paid in the amount of Rp.0, - or nil, if the income has been or is not accumulated with benefits but remains below PTKP. Before the implementation of the Minister of Finance Regulation Number: 101 / PMK.010 / 2016 concerning PTKP adjustments of Rp 4,500,000, in Surabaya City, Gresik Regency, Kab. Pasuruan, Kab. Sidoarjo and Kab. Mojokerto for Individuals who work as employees / employees and laborers are still obliged to register to get a Taxpayer Identification Number (NPWP). Another problem after the tax reduction that must be paid by WP is the increase in PTKP from all regencies / cities in Indonesia in general, for individuals who are new employees / employees and laborers or who do not have NPWP are not required to register themselves to have NPWP so the growth of new taxpayers will decrease, the impact which will then arise is the income from income tax $(\mathrm{PPh}) 21$ individuals will experience a decrease [3,9, 11, 17]. There is an interesting problem to be investigated, namely the change in Non-Taxable Income (PTKP) which has an impact on state revenue from the tax sector, domestic taxes, especially income tax for employees / employees and laborers earning below Rp 4,500,000.00, which previously did not have a tax registration number. Tax (NPWP) is not required to register to 
have a tax ID. However, this study uses data on Income Tax Article 21 payment of individual taxpayers registered in Jember Primary Tax Office, namely data on income tax article 21 in 2008 to 2018 (5x changes in PTKP) and the number of taxpayers who registered themselves during the period of 2008 to 2018. Based on these realities the researcher wanted to conduct a study with the title Analysis of Changes in Non-Taxable Income (PTKP) on the Growth Rate of Number of Individual Taxpayers and Article 21 of Income Tax Receipts at Jember's Tax Office $[1,7,14]$.

\section{RESEARCH METHODS}

Data collection methods used in this study are literature study and documentation methods in the form of secondary data collected using literature studies, obtained from various literature books and accounting journals and secondary data collected by the documentation method obtained through the Jember Primary Tax Office to retrieve the required report Personal Tax and income tax article 21 in the period 2008 - 2018 along with historical data from the Jember Pratama Tax Office. The data analysis methods of the study are descriptive statistics, ANOVA analysis and MANOVA analysis

\section{RESULT AND DISCUSSION}

In the ANOVA WPOP F table the count of the output is 477,446 , with a significant level $(\alpha)$ is $5 \%$, the numerator (df1) is 4 and the denumerator (df2) is 127 then from table F it gets 2.44 . Based on the comparison of $\mathrm{F}$ arithmetic and $\mathrm{F}$ table, it is seen that $\mathrm{F}$ arithmetic is greater than $\mathrm{F}$ table, then $\mathrm{HO}$ is rejected, that is, there is a difference in the effect of changes in the regulation of Non-Taxable Income (PTKP) on the growth rate of the number of Personal Taxpayers (WPOP).

In the ANOVA PPh $21 \mathrm{~F}$ table the count of the output is 7,780, with a significant level $(\alpha)$ is $5 \%$, the numerator ( $\mathrm{df} 1)$ is 4 and the denumerator ( $\mathrm{df} 2)$ is 127 then from table $\mathrm{F}$ the number is 2.44. Based on the comparison of the $\mathrm{F}$ arithmetic and $\mathrm{F}$ table, it can be seen that the $\mathrm{F}$ arithmetic is greater than the $\mathrm{F}$ table, then $\mathrm{H} 0$ is rejected, that is, there is a difference in the effect of changes in the Non-Taxable Income (PTKP) regulation on income tax article 21 (PPh 21) 
Tabel 1. Result of Manova Test

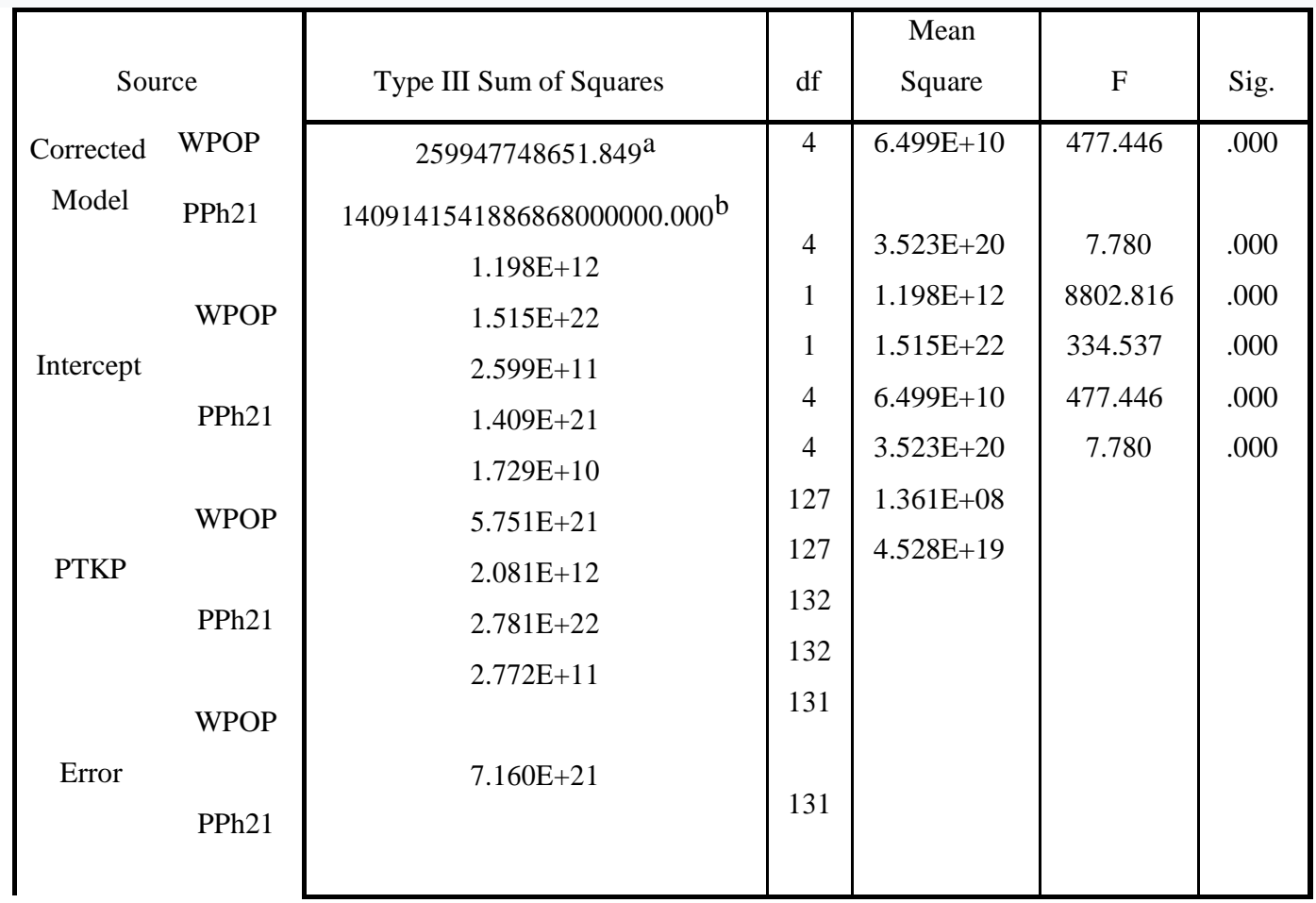

a. R Squared $=.938($ Adjusted R Squared $=.936)$

b. R Squared $=.197($ Adjusted R Squared $=.172)$

Based on table 1 we can find out the calculated $\mathrm{F}$ value for the relationship between PTKP change and total WPOP growth of 477,446 and significant at 0.05 which means there is a difference in the number of WPOP growth between PTKP changes. Likewise, the relationship between PTKP change and PPh 21 revenue gives a calculated F value of 7,780 and significant at 0.05 this means that there is a difference in $\mathrm{PPh} 21$ revenue between PTKP changes. Based on a comparison of the F calculated and significant at $0.05, \mathrm{H} 0$ is rejected, namely there is a difference in the effect of changes in the Taxable Income (PTKP) regulation on the growth rate of the number of Individual Taxpayers (WPOP) and income tax article $21(\mathrm{PPh} 21)$.

There is a difference in the effect of changes in the regulation of Non-Taxable Income (PTKP) on the growth rate of the number of Individual Taxpayers (WPOP). After calculating through the ANOVA test, a significant result of 0,000 is obtained, because a significant level of below 0.05 means that there is a significant difference in the average number of WPOP of KPP Pratama Jember from 2008,2009-2011,2012-2014,2015 and 2016- 2018. This is due to the growth in 
number of individual taxpayers recorded in Jember Primary Tax Office during the 2008-2018 period in general experienced a large and stable change.

There is a difference in the effect of changes in the regulation of Non-Taxable Income (PTKP) to the income tax article $21(\mathrm{PPh} 21)$. After calculating through the ANOVA test the significance results are 0.002 , because the significance level is below 0.05 , meaning there is a significant difference from the average number of income tax revenue 21 from 2008, 2009-2011, 20122014, 2015 and 2016. Total PPh 21 recorded at KPP Pratam Jember during 2008-2018 tends to increase. An increase in the number of PPh 21 recorded in KPP Pratama Jember illustrates the increasing amount of reported income and an increase in the number of WPOP from year to year.

There is a difference in the effect of changes in the regulation of Non-Taxable Income (PTKP) on the growth rate of the number of Individual Taxpayers (WPOP) and income tax article 21 ( $\mathrm{PPh} 21$ ). After calculating through the manova test, a significant result of 0,000 is obtained, because the significance level is below 0.05 , which means that there is a significant difference in the growth rate of the number of Personal Taxpayers (WPOP) and income tax article 21 (Income Tax 21) between changes in Non-Affected Income Tax.

\section{CONCLUSION}

Based on the descriptions that have been disclosed in the discussion, several conclusions can be drawn as answers to the main problems raised in this study, namely: 1 . There is a difference in the effect of changes in the regulation of Non-Taxable Income (PTKP) on the growth rate of the number of Individual Taxpayers (WPOP) in KPP Pratama Jember. 2. There is a difference in the effect of changes in the regulation of Non-Taxable Income (PTKP) on the level of income tax article 21 (PPh 21) because the amount of revenue is increasing. 3. There is a difference in the effect of changes in the regulation of Non-Taxable Income (PTKP) on the growth rate of the number of Individual Taxpayers (WPOP) and income tax income article 21 (PPh 21) in KPP Pratama Jember

The results of the study prove that there is a difference in the effect of changes in Non-Taxable Income (PTKP) being one of the determinants of the growth rate of Individual Taxpayers and income tax article 21 aside from the level of awareness or public compliance to register as taxpayers to pay taxes and conditions people's economy. Referring to these results, taxation 
policy makers in this case the Directorate General of Taxes in determining Non-Taxable Income (PTKP) must be equivalent to the Regency Minimum Wage (UMK) of each region and the need for periodic evaluations of the tax rates imposed on taxable income taxes related to dynamic PTKP changes every year

\section{REFERENCES}

[1] Ahmad Fitri, Tuli Hartati dan Usman. 2013. Pengaruh Perubahan Penghasilan Tidak Kena Pajak Terhadap Penerimaan Pajak Penghasilan Pasal 21 Di Kpp Pratama Gorontalo.

[2] Andiyanto Dimas, Susilo Heru, dan Catur Kurniawan Bonda. 2014. Analisis Perubahan Penghasilan Tidak Kena Pajak (PTKP) Terhadap Tingkat Pertumbuhan Jumlah Wajib Pajak Orang Pribadi Dan Penerimaan Pajak Penghasilan (Studi Pada KPP Pratama Malang Selatan Dan KPP Pratama Banyuwangi Periode 2009-2013).

[3] Anwar Chairil. 2014. Perpajakan Indonesia Teori dan Kasus, Jakarta:Mitra Wacana Media

[4] Augenio Soerjono Risky. 2016. Analisis Perubahan Pendapatan Tidak Kena Pajak (PTKP) Terhadap Tingkat Pertumbuhan Jumlah Wajib Pajak Orang Pribadi (WPOP) dan Penerimaan Pajak Penghasilan pasal 21 (PPh 21)

[5] Gunawan, Anggi. 2016. Pengaruh Perubahan Penghasilan Tidak Kena Pajak (PTKP) Terhadap Penerimaan Pajak Penghasilan (PPh) Pasal 21 (Studi Kasus pada Kantor Wilayah DJP Jawa Barat I periode 2012-2015). Skripsi. Universitas Widyatama, Bandung.

[6] Resmi, Siti. 2013. Jurnal Ilmiah Akuntansi dan Bisnis Vol. 6 No. 1, Januari. Perpajakan, Teori dan Kasus Edisi 7. Buku 1.Jakarta: Salemba Empat

[7] Kementerian Keuangan RI, 2005. Peraturan Menteri Keuangan RI (Republik Indonesia) No. 137/PMK.05/2005 mengenai Penyesuaian Besarnya Penghasilan Tidak Kena Pajak (PTKP).

[8] Kementerian Keuangan RI, 2012. Peraturan Menteri Keuangan RI (Republik Indonesia) No. 162/PMK.011/ 2012 mengenai Penyesuaian Besarnya Penghasilan Tidak Kena Pajak (PTKP). 
[9] Kementerian Keuangan RI, 2015. Peraturan Menteri Keuangan RI (Republik Indonesia) No. 122/PMK.010/2015 mengenai Penyesuaian Besarnya Penghasilan Tidak Kena Pajak (PTKP).

[10] Kementerian Keuangan RI, 2016. Peraturan Menteri Keuangan RI (Republik Indonesia) No. 101/PMK.010/2016 mengenai Penyesuaian Besarnya Penghasilan Tidak Kena Pajak (PTKP).

[11] Lewa Megawani, Kalangi Lintje,dan Pontoh Winston,2017. Analisis Perubahan Tarif Penghasilan Tidak Kena Pajak (Ptkp) Tahun 2015 Dan Tahun 2016 Terhadap Penerimaan Pajak Penghasilan (Pph) Pasal 21 Di Kantor Pelayanan Pajak Pratama Bitung.

[12] Mardiasmo,2016, Perpajakan edisi terbaru 2016, Yogyakarta : CV Andi Offset

[13] Resmi, Siti. 2013. Perpajakan, Teori dan Kasus Edisi 7. Buku 1. Penerbit PT Salemba Empat: Jakarta.

[14] Salim Michel dan Syafitri Lili, 2013. Analisis Pengaruh Kenaikan PTKP Terhadap Penerimaan Wajib Pajak Penghasilan Pada Kantor Pelayanan Pajak Pratama Palembang Ilir Barat.

[15] Sugiyono, 2016, Cara Mudah Menyusun Skripsi, Thesis Dan Disertasi. Bandung: Alfabeta.

[16] Syahrir dan Elma Heliati, 2017, Analisis Mind Map Siswa Kelas VII C Smpn 6 Kopang, Jurnal Ilmiah Mandala Education, IKIP Mataram.

[17] Undang-Undang Nomor 28 Tahun 2007 Tentang Ketentuan Umum Dan Tata Cara Perpajakan.

[18] Undang-Undang Nomor 36 Tahun 2008 Tentang Pajak Penghasilan.

[19] Waluyo, 2011. Perpajakan Indonesia, Edisi 10. Jakarta: Salemba.

[20] Waluyo, 2017. Perpajakan Indonesia, Edisi 12 . Jakarta: Salemba.

[21] www.pajak.go.id, diakses tanggal 25 Mei 2019

[22] www.bps.go.id, diakses tanggal 7 Agustus 2019

[23] Yamin, Sofyan, 2015. SPSS Complete, Edisi 2. Jakarta: Salemba Infotek ogyakarta 